\title{
Ocular changes due to systemic alpha-interferon therapy for hepatitis $\mathrm{C}$
}

\author{
Alterações oculares por uso sistêmico de alfa-interferon em pacientes com hepatite C
}

\author{
Liang Shih Jung'1 \\ Fabiano Bojikian Ciola ${ }^{1}$ \\ Raquel Dilguerian deOliveira Conceição \\ Antonio Eduardo Benedito Silva ${ }^{3}$ \\ Nilva Simerem Bueno Moraes ${ }^{4}$
}

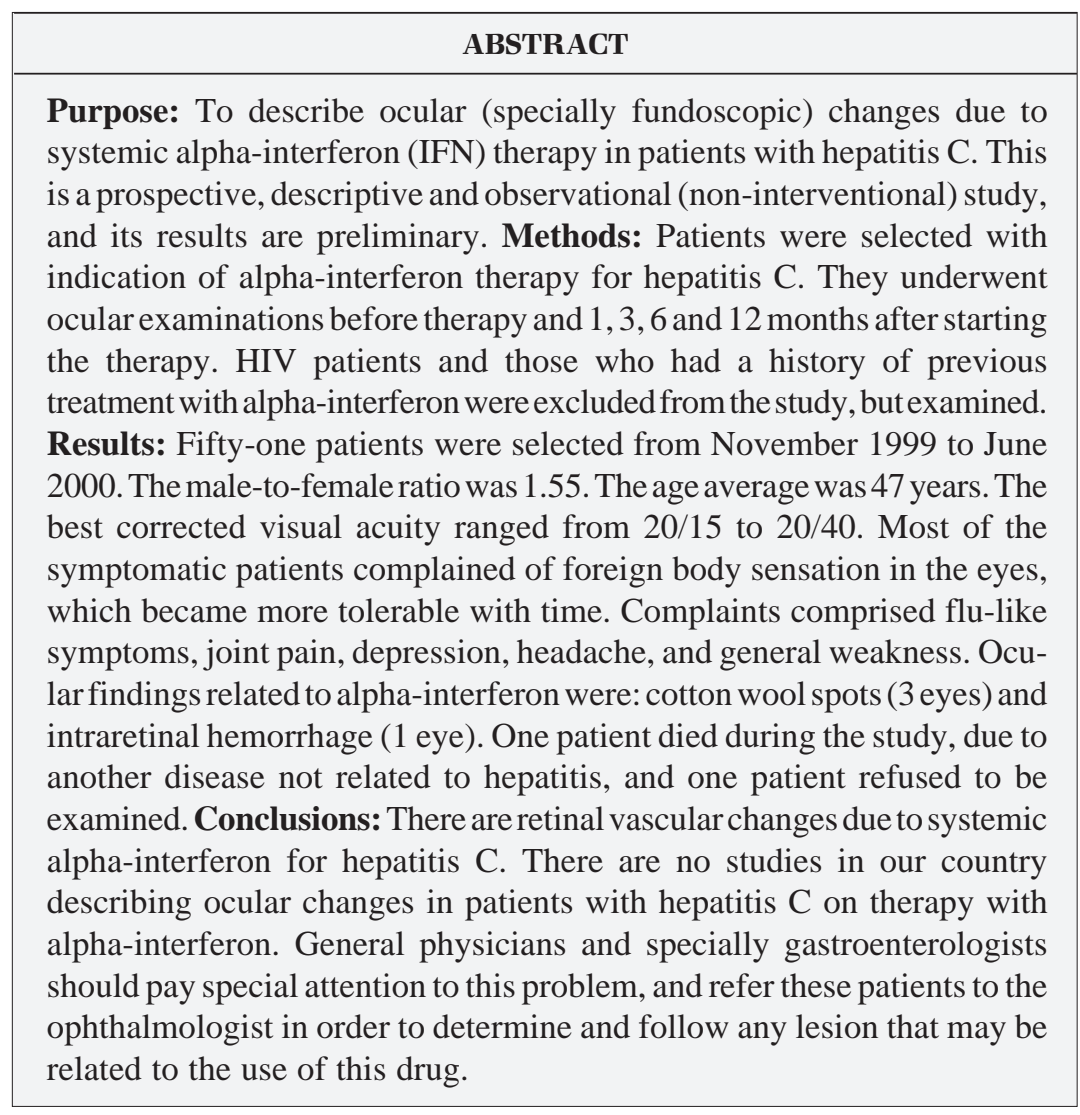

Keywords: Hepatitis C/drug therapy; Interferon-alpha/therapeutic use; Retina diseases/ etiology
Trabalho realizado no Departamento de Oftalmologia e Disciplina de Gastroenterologia Clínica da Universidade Federal de São Paulo.

${ }^{1}$ Médico Oftalmologista do Departamento de Oftalmologia da Universidade Federal de São Paulo - UNIFESP. ${ }^{2}$ Pós-graduanda em nível de Doutorado da Disciplina de Gastroenterologia da Universidade Federal de São Paulo - UNIFESP.

3 Professor Adjunto Doutor da Disciplina de Gastroenterologia da Universidade Federal de São Paulo - UNIFESP.

${ }^{4}$ Mestre em Oftalmologia pela Universidade Federal de São Paulo - UNIFESP.

Endereço para correspondência: Dr. Liang Shih Jung Rua Borges Lagoa № 933/74 - São Paulo (SP) CEP 04038-032

E-mails: liangsj@uol.com.br liang@oftalmo.epm.br

Recebido para publicação 24.10.2003

Versão revisada recebida em 23.05.2004

Aprovação em 31.05.2004

\section{INTRODUCTION}

Interferons are a group of glycoproteins that modulate the activity of the immunological system. They can be divided into 3 groups, $\alpha, \beta, \gamma$. Interferon $\alpha$ acts through monocytes and lymphocytes modulating the synthesis of immunoglobulin. Recombinant alpha-interferon (IFN) has recently been approved as a therapy for chronic hepatitis $\mathrm{C}$, for its antiviral effects and to inhibit cell proliferation.

Therapy with IFN $\alpha$ has been associated with the presence of systemic side effects, such as flu-like syndrome, arthralgia, platelet reduction, leukopenia $^{(1)}$, depression, delirium, thyroid disorders ${ }^{(2)}$ and ocular side effects ${ }^{(3-5,8-11)}$. There are descriptions in the literature ${ }^{(1,4,12-24)}$ of retinal vascular abnormalities (retinal microvascular changes, presence of cotton-wool spots, intraretinal 
hemorrhages, retinal detachment) due to this drug. Mostly, the ocular changes are transient and asymptomatic ${ }^{(12-13,16)}$. However, in some special cases an aggressive intervention should be carried out, such as retinal photocoagulation or surgery ${ }^{(10-11,23-26)}$.

\section{PURPOSE}

There are no studies in our country regarding this issue. Our purpose is to describe ocular (with special attention to fundoscopy) changes due to IFN. This is a prospective, descriptive and observational (non-interventional) study, and its results are preliminary.

\section{METHODS}

From November 1999 to June 2000, all patients with a diagnosis of chronic hepatitis $\mathrm{C}$ that fulfilled the criteria for treatment were selected. The standard therapy consisted of: IFN 3MU three times per week plus ribavirin $1 \mathrm{~g}$ daily, during 12 months. Exclusion criteria were: a) HIV co-infection, b) diabetes mellitus, hypertension or renal failure and c) previous exposure to IFN.

Ocular examination consisted of best corrected visual acuity measurement, refraction, anterior segment biomicroscopy, IOP, dilated fundoscopy and fundus biomicroscopy before and 1, 3, 6 and 12 months after starting therapy.

\section{RESULTS}

Initially, 51 patients fulfilled the criteria for IFN therapy, but 20 of them were excluded, due to the following reasons: HIV-positive $(n=3)$; previous exposure to IFN ( $n=6)$; no compliance with the follow-up visits $(n=9)$; renal failure $(n=1)$ and one patient died during the study time, due to a disease not related to hepatitis (cardiac arrest). These patients, although not included in the study, have been observed until the end of the therapy.

Follow-up was carried out for the remaining 31 patients. The male-to-female ratio was 1.58 (61\% male) and the median age was 44.1 years (range 25-66 years). General complaints were joint pain, psychiatric disturbances, headache, and general weakness (Figure 1). Best corrected visual acuity ranged from 20/15 to 20/40 and IOP levels ranged between 9 and 20 $\mathrm{mmHg}$. Symptomatic patients complained of foreign body sensation in the eyes mainly in the first 2 months of therapy, becoming more tolerable with time.

Ocular findings related to IFN were development of cotton wool spots ( 3 eyes) and retinal hemorrhage (1 eye). In one patient with previous exposure to IFN, vitreous hemorrhage, cotton wool spots, hard exudates and vascular tortuosity although asymptomatic were observed. Other ocular findings included hordeolum $(\mathrm{n}=1)$ and toxoplasmosis scarred chorioretinitis $(n=2)$. Two HIV patients presented unilateral scarred

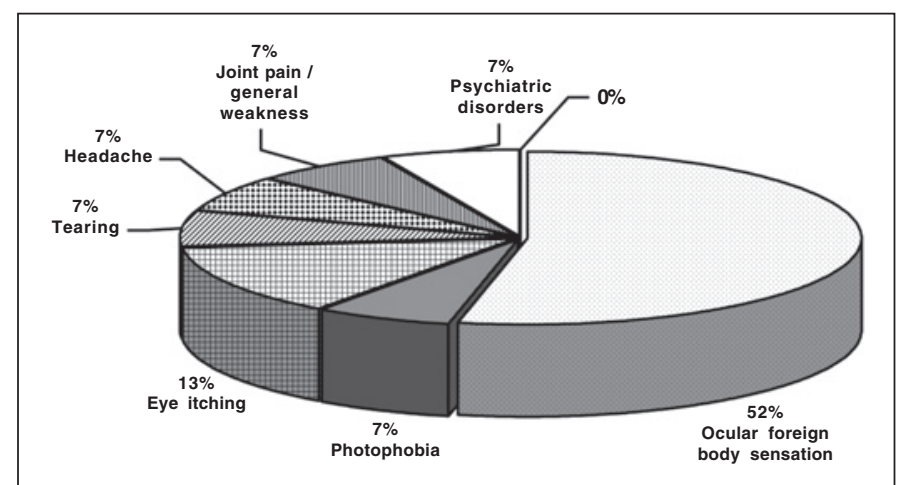

Figure 1 - Ocular and general complaints of patients undergoing IFN therapy

retino-choroiditis due to toxoplasmosis, one of which was characterized as Jensen's papillitis.

\section{DISCUSSION}

In our study, there were no cases of severe ocular complications due to the administration of systemic IFN. The only case of retinopathy started less than 2 months after the beginning of the therapy, and did not lead to any ocular symptom. Still, the retinopathy did not resolve spontaneously by the time this patient died of cardiac infarction. The other case of retinopathy was excluded from the study, due to past personal history of hypertension, diabetes mellitus and chronic renal insufficiency, but was followed up. Therefore, the retinal findings in this patient could not be associated only with IFN itself.

In the international literature, the incidence of retinopathy associated with IFN ranges from 18 to $86 \%{ }^{(27)}$. This variation can be explained by the amount of analyzed patients, the associated risk factors, and indication of IFN administration. Some studies report disappearance of the retinopathy even with maintenance of the therapy ${ }^{(2,4,12,16)}$, while others describe its persistence ${ }^{(13,15)}$. There are several clinical evolutions, and most of them are benign. One single case is about a patient that presented a disarrangement of the basic structures of the eye and infiltration of inflammatory cells, leading to eyeball rupture $^{(25)}$. This is probably the most severe case of ocular complication by IFN.

The pathogenesis of retinopathy is not totally clear. Several theories have been formulated to explain the mechanisms of retinal dysfunction:

- Obstruction of axoplasmatic flow secondary to ischemia of the retinal vasculature, causing cotton wool spots ${ }^{(22,28)}$.

- The presence of cotton-wool spots and retinal hemorrhages indicates that probably there is an impairment of retinal blood circulation and somehow there might be retinal ischemia ${ }^{(1,14,21)}$. According to the authors, the dysfunctions are similar to those found in diabetic retinopathy.

- Decreased platelet counts, increased triglyceride levels and diabetes mellitus. Hypoalbuminemia decreases the 
plasma oncotic pressure difference between interstitial fluids ${ }^{(1,15)}$.

- Intra-arterial obstruction by leukoaggregated embolization results from complement activation with IFN alpha causing synergistic elevation of C5a levels, the complement component responsible for granulocyte shape alteration and aggregation $^{(1,20,28)}$. According to those studies, C5a levels increased 5 to 10 times in patients with retinal complications on IFN therapy as compared with those without retinal complications. IFN alpha has been shown to increase leukocyte adhesion to vascular endothelium in rats ${ }^{(15)}$.

The three typical fundus changes are: retinal hemorrhage, cotton-wool spots, and nerve fiber layer defect ${ }^{21}$. Patients with previous history of diabetes mellitus are more susceptible to the development of retinopathy $\mathrm{y}^{(1,4,14-15)}$. Ocular pain is not likely to be related to retinopathy ${ }^{(16-17,21)}$. Because this retinopathy is usually mild and seldom induces visual symptoms, the therapy can be continued in most patients. However, severe retinal damage carries the risk of complete loss of vision. Therefore, careful monitoring of retinal lesions is required in patients receiving IFN therapy, especially in those with underlying diabetes mellitus or hypertension.

There is no classification for IFN-induced retinopathy, like diabetic retinopathy. Therefore there is no rule for suspending the use of interferon in patients who develop retinopathy or any other ocular side effects. The common sense for most authors is that careful monitoring should be performed in the presence of any ocular sign, even without symptoms $^{(3,12-14,16,19-20,27,29)}$. The ophthalmic intervention is of crucial importance in order to keep satisfactory ocular function, even if invasive procedures are necessary, such as laser retinal photocoagulation or eye surgery ${ }^{(8,25)}$.

\section{CONCLUSION}

In the present study, retinal abnormalities, although asymptomatic were found in the eyes of patients undergoing IFN therapy for hepatitis C. In our country, there are no studies describing the features of these microvascular abnormalities or their epidemiology. Since this is a preliminary study, further research on this issue must be carried out, probably with a more significant amount of cases. Patients undergoing the therapy should always be referred to the ophthalmologist in order to determine and follow any lesion that may be related to the use of this drug.

\section{RESUMO}

Objetivo: Avaliar alterações oculares (em especial lesões fundoscópicas) em pacientes com hepatite $\mathrm{C}$ tratados com alfainterferon (IFN). Métodos: Estudo prospectivo, descritivo e observacional de pacientes com hepatite $\mathrm{C}$ do serviço de Gastroenterologia da UNIFESP com indicações de uso de alfa- interferon entre novembro de 1999 e junho de 2000. Esses pacientes foram submetidos a exame oftalmológico completo antes e 1, 3, 6 e 12 meses após o início do tratamento. Pacientes HIV positivos, ou com exposição prévia à droga foram excluídos. Resultados: De um total de 51 pacientes selecionados, 31 foram acompanhados. A relação masculino-feminino foi de 1,55 , e a média de idade de 47 anos. A acuidade visual corrigida variou de 20/15 a 20/40. Vinte e dois por cento dos pacientes queixaram-se de sensação de corpo estranho, principalmente nos dois primeiros meses de terapia. Queixas gerais foram: artralgia, cefaléia, depressão, fraqueza muscular. Achados oculares foram: hemorragia retiniana (um olho) e exsudatos moles (três olhos), todos assintomáticos. Em um paciente com história pregressa de tratamento com interferon, observou-se presença de hemorragia vítrea, exsudatos duros e moles e tortuosidade vascular. Um paciente faleceu durante o tratamento por infarto cardíaco. Conclusões: Existem alterações oculares por uso sistêmico de alfa-interferon. Não existem estudos no nosso país descrevendo essas alterações. Médicos clínicos gerais e gastroenterologistas devem prestar atenção a esse tipo de problema, e encaminhar os pacientes a um serviço de oftalmologia para acompanhamento paralelo.

Descritores: Hepatite C/quimioterapia; Alfa-interferon/uso terapêutico; Retinopatia/etiologia.

\section{REFERENCES}

1. Tokai R, Ikeda T, Miyaura T, Sato K. Interferon-associated retinopathy and cystoid macular edema. Arch Ophthalmol. 2001;119(7):1077-9.

2. Okanoue T, Sakamoto S, Itoh Y, Minami M, Yasui K, Sakamoto M, et al. Side effects of high-dose interferon therapy for chronic hepatitis C. J Hepatol. 1996;25(3):283-91.

3. Purvin VA. Anterior ischemic optic neuropathy secondary to interferon alfa. Arch Ophthalmol. 1995;113(8):1041-4.

4. Hayasaka S, Fujii M, Yamamoto Y, Noda S, Kurome H, Sasaki M. Retinopathy and subconjunctival haemorrhage in patients with chronic viral hepatitis receiving inteferon alfa. Br J Ophthalmol. 1995;79(2):150-2.

5. O'Neill DP. The eye and liver disorders. Eye. 1992;6(Pt 4):366-70.

6. Zegans ME, Anninger W, Chapman C, Gordon SR. Ocular manifestations of hepatitis C virus infection. Curr Opin Ophthalmol. 2002;13(6):423-7.

7. Moazami G, Auran JD, Florakis GJ, Wilson SE, Srinivasan DB. Interferon treatment of Mooren's ulcers associated with hepatitis C. Am J Ophthalmol. 1995;119(3):365-6.

8. Baratz KH, Fulcher SF, Bourne WM. Hepatitis C-associated keratitis. Arch Ophthalmol. 1998;116(4):529-30.

9. Fukumoto Y, Shigemitsu T, Kajii N, Omura R, Harada T, Okita K. Abducent nerve paralysis during interferon alpha-2a therapy in a case of chronic active hepatitis C. Intern Med. 1994;33(10):637-40.

10. Gillies MC, Garrett SK, Shina SM, Morlet N, Taylor HR. Topical interferon alpha $2 \mathrm{~b}$ for corneal haze after excimer laser photorefractive keratectomy. J Cataract Refract Surg. 1996;22(7):891-900.

11. Leyland M, Torok ME, Acheson J, Foster GR. Hepatitis C virus infection is not associated with a marked increase in the prevalence of ophthalmic morbidity. Eye. 2000;14(Pt 6):889-91.

12. Peres-AlvareZ AF, Jimenez-Alonso J, Reche-MOLINA I, Leon-Ruiz IL, Hidalgo-Tenorio C, Sabio JM. Retinal vasculitis and vitreitis in a patient with chronic hepatitis C virus. Arch Intern Med. 2001;161(18):2262.

13. Jain K, Lam WC, Waheeb S, Thai Q, Heathcote J. Retinopathy in chronic hepatitis $\mathrm{C}$ patients during interferon treatment with ribavirin. $\mathrm{Br} \mathrm{J}$ Ophthalmol. 2001;85(10):1171-3.

14. Esmaeli B, Koller C, Papadopoulos N, Romaguera J. Interferon-induced retinopathy in asymptomatic cancer patients. Ophthalmology. 2001;108(5):858-60. 
15. Willson RL, Ross RD, Willson LM, Cohen G, Redfield TL, Gitter KA. Interferon-associated retinopathy in a young, insulin-dependent diabetic patient. Retina. 2000;20(4):413-5.

16. Norcia F, Di Maria A, Prandini F, Redaelli C. Natural interferon therapy: optic nerve ischemic damage? Ophthalmologica. 1999;213(5):339-40.

17. Kadayifcilar S, Boyacioglu S, Kart H, Gursoy M, Aydin P. Ocular complications with high-dose interferon alpha in chronic active hepatitis. Eye. 1999;13 (Pt 2):241-6.

18. Abe T, Nakajima A, Matsunaga M, Sakuragi S, Komatsu M. Decreased tear lactoferrin concentration in patients with chronic hepatitis $\mathrm{C}$. Br J Ophthalmol. 1999;83(6):684-7.

19. Manesis EK, Moschos M, Brouzas D, Kotsiras J, Petrou C, Theodosiadis G, et al. Neurovisual impairment: a frequent complication of alpha-interferon treatment in chronic viral hepatitis. Hepatology 1998;27(5):1421-7. Comment in: Hepatology. 1998;27(5):1441-2.

20. Sugano S, Suzuki T, Watanabe M, Ohe K, Ishii K, Okajima T. Retinal complications and plasma C5a levels during interferon alpha therapy for chronic hepatitis C. Am J Gastroenterol. 1998;93(12):2441-4.

21. Kawano T, Shigehira M, Uto H, Nakama T, Kato J, Hayashi K, et al. Retinal complications during interferon therapy for chronic hepatitis C. Am J Gastroenterol. 1996;91(2):309-13.
22. Guyer DR, Tiedeman J, Yannuzzi LA, Slakter JS, Parke D, Kelley J, et al. Interferon-associated retinopathy. Arch Ophthalmol. 1993;111(3):350-6.

23. Schulman JA, Liang C, Kooragayala LM, King J.Posterior segment complications in patients with hepatitis $\mathrm{C}$ treated with interferon and ribavirin. Ophthalmology. 2003;110(2):437-42.

24. Hejny C, Sternberg P, Lawson DH, Greiner K, Aaberg TM Jr. Retinopathy associated with high-dose interferon alfa-2b therapy. Am J Ophthalmol. 2001; 131(6):782-7.

25. Yamada H, Mizobuchi K, Isogai Y. Acute onset of ocular complications with interferon. Lancet 1994;343(8902):914.

26. Kuga K, Hasumura S, Nagamori S, Toda G, Kitahara K.Intraocular hemorrhage developing during interferon therapy. Intern Med. 1996;35(1):15-8.

27. Hayasaka S, Nagaki Y, Matsumoto M, Sato S. interferon-associated retinopathy. Br J Ophthalmol. 1998;82(3):323-5.

28. Sugano S, Yanagimoto M, Suzuki T, Sato M, Onmura H, Aizawa H, et al. Retinal complications with elevated circulating plasma C5a associated with interferon-alpha therapy for chronic active hepatitis C. Am J Gastroenterol. 1994;89(11):2054-6.

29. Pivetti-Pezzi P, Accorinti M, Pirraglia MP, Priori R, Valesini G. Interferon alpha for ocular Behcet's disease. Acta Ophthalmol Scand. 1997;75(6):720-2. 